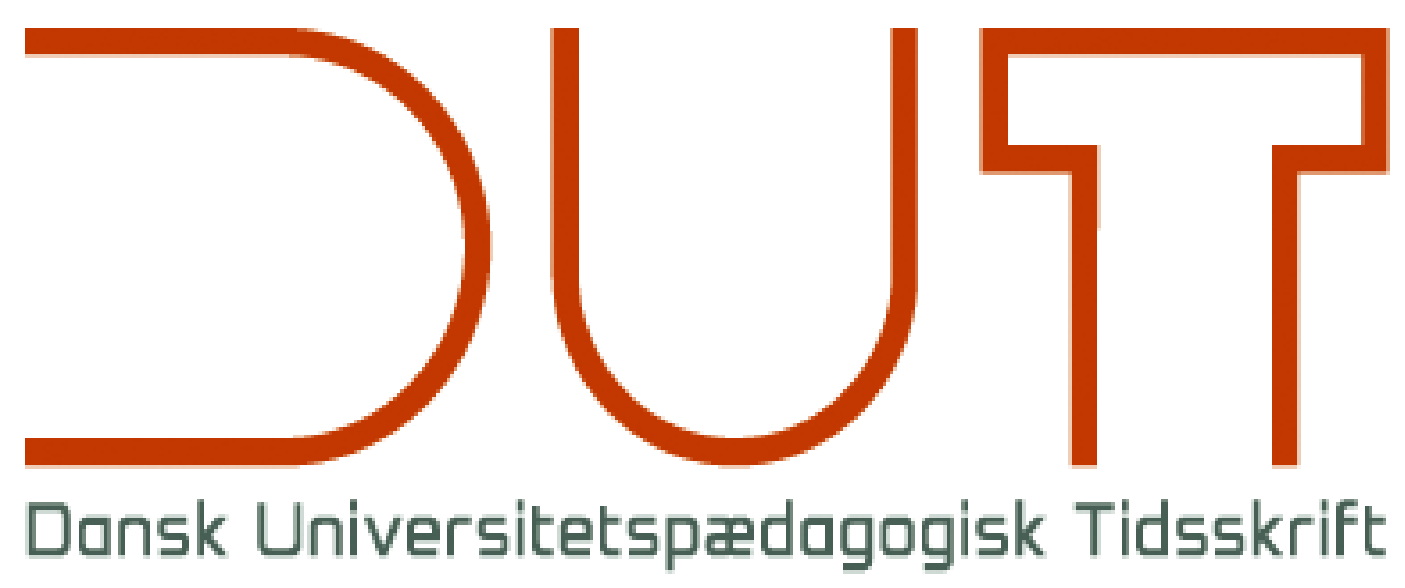

Tema

Autentisk læring

Årgang 15 nr. 29 / 2020

Titel

DUT Guide: Studielederråd

Forfattere

Jens Dolin

Sidetal

$128-135$

Udgivet af

Dansk Universitetspædagogisk Netværk, DUN

URL

> http://dun-net.dk/

Betingelser for brug af denne artikel

Denne artikel er omfattet af ophavsretsloven, og der må citeres fra den. Følgende betingelser skal dog være opfyldt:

- Citatet skal være i overensstemmelse med "god skik"

- Der må kun citeres „i det omfang, som betinges af formålet“

- Ophavsmanden til teksten skal krediteres, og kilden skal angives ift. ovenstående bibliografiske oplysninger. 


\section{DUT Guide: Studielederråd}

Jens Dolin ${ }^{a, 1}$

a Professor emeritus, Institut for Naturfagenes Didaktik, Københavns Universitet

\section{Praktiske pointer}

1. Du skal ville noget med jobbet

2. Få klarhed over rollen og betingelserne

3. Undervisning er vigtigere end forskning

4. Forskningsbaseret undervisning er også undervisning baseret på forskning i undervisning

5. Basér dine beslutninger på valide data

6. Find gode legekammerater, og inddrag de studerende

7. Pas på dig selv

\section{Baggrund}

Studielederens officielle rolle er fastlagt i Universitetsloven:

Studielederen har til opgave i samarbejde med studiencevnet at forestå den praktiske tilrettelaeggelse af undervisning og af prøver og anden bedømmelse, der indgår i eksamen. Studielederen godkender opgaveformulering og afleveringstidspunkt for kandidatspecialet samt $i$ tilknytning hertil en plan for vejledningen af den studerende. (https://danskelove.dk/universitetsloven)

Rollen er så løst beskrevet, at der er rig mulighed for fortolkning og udvikling af forskellige praksisser, og det er også, hvad der er sket. I sin ph.d. interviewede Thomas Harboe (2013) en række studieledere om deres opfattelse af studielederrollen, og der tegnede sig et billede af en løst defineret ledelsesfunktion, som var præget af forhandling og løse koblinger til deres omgivelser. Studielederne gav klart udtryk for, at deres arbejde var stærkt underlagt den New Public Management-politik, der på det tidspunkt gav sig udslag i styringsmæssige reformer, som de så skulle implementere. Sådan er det stadig. Uddannelsesområdet er præget af stramninger og kontrol og reguleringer, selv om der ses tendenser til, at andre værdier begynder at præge debatten og den førte politik. Men når universiteterne presses af NPMtiltag som $\mathrm{fx}$ akkreditering eller af nedskæringstiltag som $\mathrm{fx}$ fremdriftsreform og $2 \%$ nedskæring, så er det ofte studielederen, der skal få det til at fungere.

Studielederen er således en typisk mellemleder med mange opgaver og et ansvar for, at uddannelserne rent faktisk fungerer - uden formel kompetence til at bestemme over ressourcer og personale. Klemt mellem ledelse, VIP'ere/TAP'ere og studerende og under meget forskellige vilkår, hvad angår det timemæssige omfang af ledelsesfunktionen, og hvad angår

\footnotetext{
${ }^{1}$ Kontakt: dolin@ind.ku.dk
} 
nærhed til ledelsesstrengen, skal studielederen få enderne til at mødes på en måde som gør alle tilfredse - eller lige utilfredse.

Således kan Harboe et al. (2017) slå fast, at studieledelse "... kræver studieledere, der til stadighed kan balancere kompetent mellem pædagogisk og administrativ ledelse samt mellem det personlige, det lokale og det organisatoriske niveau på universitetet" (s. 48).

Det følgende er nogle råd til at kunne navigere helskindet og helhjertet gennem studieledelsens minefyldte farvand.

\section{Du skal ville noget med jobbet}

Det er en dårlig indgang til studielederjobbet, hvis du har accepteret det som et borgerligt ombud - flaskehalsen pegede på dig, men du er helst fri. Det skal ikke være en sur pligt, du er blevet pålagt, men en mulighed for at få gennemført nogle af dine undervisnings-/uddannelsesmæssige visioner. Og hvis du ikke har nogle sådanne, skal du overbevise din ledelse om, at du ikke er den rette på posten. Eller se at få nogle! Som eksempel indeholder denne artikels råd 3 og 4 nogle grundlæggende principper og holdninger til undervisning, som kan udgøre et værdimæssigt grundlag for at få realiseret nogle mere konkrete tiltag. Men det vil ikke være let.

Universiteterne er på mange måder meget træge systemer, hvor ændringer ofte er oppe imod både universitetets egne traditioner og eksterne styringsforhold. Det kan derfor i praksis være nødvendigt at balancere mellem at tilgodese et teknokratisk ledelsesgrundlag (det kunne $\mathrm{fx}$ være din nærmeste ledelse), der ofte er baseret på tal, målopfyldelse, ledelsesstrengens logik m.m., og et mere værdibaseret ledelsesgrundlag, som følger nogle traditionelle universitetsværdier, såsom dialog, det antiautoritære, den studerende i centrum m.m., som de fx er beskrevet af Christiansen et al. (2013). Men fronterne kan trækkes op på andre måder. Det kan være, at ledelsen gerne vil fremme nogle nye, pædagogiske tiltag, mens dele af underviserkorpset anser sådanne ændringer som et angreb på deres traditionelle metodefrihed. Pointen er, at uanset hvem der forfægter hvilke synspunkter, og uanset hvor mange opgaver med løbende deadlines man pålægges, så er det vigtigt at arbejde for de værdier, som man er gået ind i jobbet med. Ellers risikerer man at ende som det, Finn Wiedemann (2018) karakteriserer som en pedel: "Det meste af tiden er studielederen dog snarere en universitetspedel, som skal løse simple driftsspørgsmål uden at have tid til eller mulighed for at involvere sig i opgaver af strategisk og udviklingsmæssig karakter" (s. 128).

Man kan som studieleder let få den opfattelse, at det afgørende er alt det, der kan måles: overholdelse af svarfrister, frafald, arbejdsløshedsdata, evalueringer m.m. Ofte overses det, at forbedring af de målbare data (forhåbentlig) er baseret på hensigtsmæssige kvalitative og strategiske tiltag.

Det er vigtigt, at drift og tilpasning ikke tager al tiden, så der ikke er overskud til at kunne arbejde for dine visioner og i et større perspektiv udvikle og kvalitetsforbedre uddannelserne og undervisningen. Derfor skal du som studieleder dels samarbejde med linjeledelsen ( $f x$ en viceeller institutleder), dels være løbende skarp på, hvad der er muligt, og hvad du bør glide af på, hvilke opgaver der skal prioriteres højest og hvilke du kan tage lettere på og måske få hjælp til. Men fasthold et fokus på at få realiseret dine ideer og visioner. Og husk: Du er (forhåbentlig) indstillet af studienævnet, den sidste rest af demokrati i universitetssystemet, så du har opbakning fra basis. 


\section{Få klarhed over rollen og betingelserne}

For at kunne gennemføre dine visioner - eller bare for $\mathrm{i}$ det hele taget at overleve i et stressende krydsfelt - må du sikre dig så gode arbejdsbetingelser som muligt. Studielederfunktionen indeholder ganske mange administrative rutineopgaver, og de skal helst ikke tage al energien fra det, du gerne ville med jobbet. Før du accepterer jobbet, kan du evt. spørge den tidligere studieleder, hvad der er svært og arbejdstungt ved jobbet, og hvordan du kan aflastes administrativt - og få lovning på, at du som studieleder får de nødvendige ressourcer. Det kan være som en hensigtserklæring, men bedre er det, hvis du på forhånd har nogle bestemte områder, du gerne vil arbejde med og have accept af og ressourcer til at gøre noget ved. Sørg for at få det hele på mail, for selv om samtaler er gode til at opnå enighed, så er det skrevne ord mere forpligtende. Skriv evt. en mail til dine samtalepartnere efter et møde, hvor du opridser det, I blev enige om. Du kan også ved større afgrænsede opgaver bede om en resultatkontrakt med ledelsen, hvor du har krav på et engangstillæg, når opgaven er fuldført.

Dine ønsker til gode arbejdsbetingelser hænger tæt sammen med, hvilken ledelsesrolle du selv og din arbejdsgiver forestiller sig, du skal varetage som studieleder. Før du accepterer jobbet, kan det være godt at have en samtale om, hvilke perspektiver for udvikling af studielederfunktionen du selv og din ledelse forstiller sig. Skal funktionen knyttes tættere til ledelseslaget, $\mathrm{fx}$ ved at den tildeles egentlige ledelsesfunktioner eller samarbejder tæt med dekanatet om ledelsesbeslutninger, med fare for at fjerne sig fra undervisere og studerende? Denne løsning anbefales entydigt af Kvalitetsudvalget (2. delrapport s. 128). Eller skal studieledelsesfunktionen aflastes ved, at nogle af opgaverne varetages af administrativt personale? Der er ganske mange modeller i spil, men det virker sandsynligt, at jo mindre formelt studielederfunktionen er beskrevet, jo mere afhænger dens succesfulde realisering af personlige egenskaber hos studielederen og af vedkommendes opbakning i studiemiljøet.

\section{Undervisning er vigtigere end forskning}

Dette er sagt lidt provokerende, men er ikke helt forkert. Det afhænger selvfølgelig af, hvilken målestok man bruger, og det er uden for artiklens rammer (og forfatterens kompetencer) at vurdere fx de samfundsøkonomiske effekter af henholdsvis forskningen og undervisningen på de videregående uddannelser. Der produceres meget specialiseret viden på de videregående uddannelsesinstitutioner, og deres forskere har en vigtig rolle som i vid udstrækning uafhængige eksperter. Men jeg vil hævde, at universiteternes største bidrag til samfundet er de kandidater, som de uddanner til at udfylde vigtige funktioner i samfundet. Denne argumentation kan anes i en af Kvalitetsudvalgets rapporter:

"Videregående uddannelse er derved ikke alene en forudsætning for, at samfundet kan producere ny viden, men også en forudsætning for at anvende ny viden. Hvert år produceres op mod to millioner nye videnskabelige artikler, som hele verden i princippet har adgang til. Det er naturligvis vigtigt for et land at bidrage til denne vidensproduktion. Men det er endnu mere afgørende at have kapacitet til at udbrede og omsætte den nye viden til gavn for samfundet gennem veluddannede borgere" (Udvalg for Kvalitet og Relevans i de Videregående Uddannelser, 2014, s. $3 f$ (her citeret uden noter)).

Det er oplagt, at graden af 'veluddannethed' er helt afhængig af kvaliteten i uddannelserne, og det er en central pointe, at universiteternes massive prioritering af forskningen, og arbejde med at skaffe store forskningsbevillinger, har haft en uheldig negativ effekt på 
undervisningens kvalitet. Traditionelt har forskningen været i front på universiteterne, både hvad angår bedømmelse af universiteternes status, og hvad angår de ansattes løn og avancement. Mange af de sidste års rapporter om videregående uddannelser udtrykker berettiget - bekymring over undervisningens ringe status i forhold til forskningen. Selv om der er sket fremskridt, og der mange steder lægges større vægt på undervisningen, og der er etableret en formel ligestilling, er det stadig sådan, at ansættelser og forfremmelser primært foretages på baggrund af forskningsresultater. De fleste ansatte vil gerne engagere sig i undervisning, men de siger meget realistisk, at det vil være på bekostning af forskningsindsatsen - og dermed på bekostning af vedkommendes akademiske karriere. Kun én ud af ti universitetsundervisere mener, at kvaliteten af deres undervisning betyder noget, $\mathrm{i}$ forhold til hvad de tjener og i forhold til deres forfremmelsesmuligheder (Udvalg for Kvalitet og Relevans i de Videregående Uddannelser, 2015, s. 20).

Afsnitsoverskriften er derfor ikke et råd, men snarere en indsigt, man som studieleder kan have i baghovedet, når jobbet føles op ad bakke, samtidig med at man arbejder på at sikre en ligeværdighed mellem forskning og undervisning. Som det udtrykkes i Kvalitetsudvalgets anden rapport:

"Det nuværende offentlige bevillingssystem giver efter udvalgets opfattelse incitamenter til fremme forskningens kvalitet, men ikke til at fremme kvalitet og relevans i de videregående uddannelser. Derfor finder udvalget, at der fra centralt hold er behov for i højere grad end tilfældet er i dag at sidestille forskning og uddannelse i de økonomiske incitamentsstrukturer, der er for institutionerne og deres ansatte" (Udvalg for Kvalitet og Relevans i de Videregående Uddannelser, 2014, s. 135).

Erkendelsen af, at undervisningen bør have status på niveau med forskningen, kan også udgøre et grundlæggende drive for ens arbejde som studieleder ved løbende at påpege, at kompetente kandidater udvikles gennem højkvalitetsundervisning - ikke gennem studiefremdrift og dimensionering og ikke gennem selvstændiggjort forskning.

\section{Forskningsbaseret undervisning er også undervisning baseret på forskning i under- visning}

Universiteterne skal levere forskningsbaseret undervisning. Det er indskrevet i Universitetslovens \$2, og der er opbygget et omfattende begrebsapparat til forståelse heraf (Dohn og Dolin, 2013; Damsholt et al., 2018).

Det er en vigtig studielederfunktion at sikre dette. Men pointen med overskriften er egentlig en helt anden, nemlig at undervisning som aktivitet også bør være baseret på forskning i, hvad god undervisning er. God undervisning er heldigvis et vidt begreb, og det er ikke muligt at pege på én bestemt måde at tilrettelægge undervisningen på som den rigtige - ud over på et relativt højt generaliseringsniveau (Dolin og Ingerslev, 2017). Men selv sådanne generelle retningslinjer for god undervisning, som fx effektiv brug af feedback, studenteraktivering etc., skal tilpasses den konkrete situation. Derfor er kendskab til forskellige pædagogisk-didaktiske metoder og evnen til at kunne vælge mellem og meningsfuldt implementere forskellige undervisningstiltag en central kompetence for den gode underviser - og dermed er det vigtigt for en studieleder at kunne indgå kvalificeret i sådanne overvejelser.

Som følge heraf forudsætter studielederjobbet kendskab til didaktiske grundbegreber. Hvis du ikke har taget et universitetspædagogisk grundkursus, kan du evt. følge et for at finde ud af, 
hvorledes det universitetspædagogiske felt aktuelt ser ud. Hold dig desuden løbende orienteret, fx ved at læse Dansk Universitetspædagogisk Tidsskrift og deltage i DUN-konferencerne. Herigennem får du også nogle flere nuancer på hele det uddannelsespolitiske felt, som kan være nyttige til at supplere mere officielle kanaler.

\section{Basér dine beslutninger på valide data}

Her er vi inde på et centralt forhold i studieledelsen. Uddannelsespolitiske og undervisningsmæssige beslutninger bør tages på et så velinformeret grundlag som muligt. "To nylige rapporter peger på, at dette ikke er tilfældet, og at det især halter med hensyn til det mere systematiske og standardiserede ledelsesgrundlag (Kvalitetsudvalget 2015; Rigsrevisionen, 2008)". Sådan skriver Thomas Harboe, Camilla Rump, Jette Hyldegård og Jesper Bruun (2017) i deres artikel om informationskompetente studieledere (s. 49). Her gennemfører de selv en spørgeskemaundersøgelse af 66 studieledere og konkluderer, at "... studielederne bruger uformelle og anekdotiske videnskilder i signifikant højere $\operatorname{grad}(p<0,05)$, end de bruger administrative eller forskningsbaserede kilder til viden om pædagogiske forhold (bredt forstået)" (s. 59). Rigsrevisionsrapporten siges at tegne "et billede af en ad hoc-præget studieledelse uden helhedsorientering og uden systematisk brug af de udviklingsredskaber, der faktisk findes" (op.cit., s. 49), og Kvalitetsudvalget refereres for at anbefale "... flere standardiserede kvantitative opgørelser af generel og systematisk karakter". Herved forstås studenterevalueringerne som et systematisk og standardiseret ledelsesgrundlag.

Hverken den overvejende anekdotiske eller den overvejende administrative tilgang giver et tilstrækkeligt vidensgrundlag for kvalitetsudvikling. Det første giver sig selv, men også den administrative tilgang, ofte baseret på kvantitative evalueringsdata, som traditionelt tillægges stor vægt i administrative systemer, er det vigtigt at advare imod.

Ret omfattende forskning konkluderer, at studenterevalueringer af kursusmoduler er ikke-valide og nogle gange direkte misvisende. Således udtaler en række forskere/undervisere at:

“... standardiserede studenterevalueringer er meget problematiske ift. at vurdere og udvikle kvalitet i uddannelser; ja, endda at de kan modvirke kvalitetsudvikling. Her er fem af de mest slående problemer med studenterevalueringer, som forskningen har påvist:

- Der er ingen sammenhæng mellem gode evalueringer og læringsudbytte - måske endda det modsatte

- Studerendes evalueringer afhænger af, om de forventer at få en god karakter

- Fokus på at få gode evalueringer kan få undervisere til at sænke kursers læringsniveau

- Studerende giver dårligere evalueringer af undervisere, der stiller store krav til dem

- Studerende giver lavere evalueringer til kvindelige undervisere"

(Dalsgård et al. (2017)).

På trods heraf vil man som studieleder utvivlsomt komme til at arbejde en del med de individuelle studenterevalueringer af kurser, og fremover vil dette arbejde sandsynligvis blive suppleret med en forholden sig til studenterevalueringer på et mere aggregeret niveau. Et enigt Folketing vedtog i 2017 en aftale om et nyt bevillingssystem for de videregående uddannelser, som lader op til $5 \%$ af institutionernes grundtilskud afhænge af resultatet af en spørgeskemaundersøgelse blandt institutionens studerende. Det såkaldte 'Læringsbarometer' (https://ufm.dk/uddannelse/statistik-og-analyser/laeringsbarometer) afdækker studerendes oplevelser af læringsmiljøet på deres uddannelse og deres egne tilgange til læring gennem 
spørgsmål om henholdsvis feedback, motivation, underviserinteraktion m.m. samt læringstilgang og dybde/overfladelæring. De 37 spørgsmål retter sig i vidt omfang mod de studerendes (opfattelse af) undervisning(en) og egen læring, hvilket utvivlsomt vil kunne generere interessante data. Men det vil være data, som ikke kan stå alene. Wilson et al. (1997, p. 48) anbefaler, at sådanne aggregerede undersøgelser på institutionsniveau skal ses som udgangspunkt snarere end slutpunkt i enhver evalueringsproces, og at undersøgelsens resultater skal bruges til at indikere, hvor man kan undersøge for underliggende faktorer, der kan påvirke undervisningskvaliteten.

Hvad er så 'gode' data, som studielederen kan tage beslutninger ud fra? Harboe et al. (2017) skitserer en tredje studieledelsesmodel som alternativ til den kollegiale og den bureaukratiske, nemlig 'scholarship of educational leadership'. Denne studielederposition indebærer en forskningstilgang til viden om den undervisning og de uddannelser, man skal kvalitetsudvikle. Omhyggeligt, metodisk, skeptisk, transparent samler man ny viden, som man fremlægger for og diskuterer med sine undervisere, studerende og ledere. Dette vil for de fleste være en ny studielederrolle, som skal bygges op fra grunden, og det er ikke på forhånd fastlagt, hvilke elementer der skal indgå i den.

Studenterevalueringer vil utvivlsomt være en del af datagrundlaget, men langt fra den vigtigste og derfor suppleret med mange andre - som du selv må udvikle. Efter en sønderlemmende kritik af skriftlige studenterevalueringer kommer Hornstein (2017) og Stark \& Freishtat (2014) med nogle præcise advarsler i forhold til brug af dem og en række forslag til andre datakilder, primært observationer og indsamling af andre former for materiale.

Men først og fremmest: Snak med underviserne og de studerende. Kun $60 \%$ af de 200 medvirkende studieledere i 2008-undersøgelsen havde halvårligt eller årligt møde med de interne undervisere, og kun $45 \%$ havde halvårligt eller årligt møde med de eksterne undervisere (her refereret efter Harboe et al. (2017, s. 49)). Dette er tilfældet til trods for, at det er underviserne og de studerende, der har skoene på og derfor ved, hvor de trykker, og kun ved at tale med dem får du et dækkende billede af vilkår og ønsker. Og det giver ikke anekdotiske data, hvis samtalerne er strukturerede og omfatter et repræsentativt udsnit af populationen.

Som leder har du magt og ressourcer til at tage initiativer. Opret $\mathrm{fx}$ dialogfora hvor forskellige grupper sender repræsentanter, og afhold jævnlige møder med en grundig dagsorden (og kaffe og kage og frugt), gerne suppleret med et oplæg fra en af deltagerne eller en ekstern person. Sæt $f x$ undersøgelser i gang af relevante problematikker.

Samarbejd gerne med det pædagogiske center. Du kan her få støtte til at indsamle og tolke data om undervisningen.

\section{Find gode legekammerater, og inddrag de studerende}

Som det tydeligt fremgår af det foregående, kan du ikke fungere tilfredsstillende som studieleder uden støtte fra og samarbejde med en række nøglepersoner, som du ofte selv må samle sammen. Find centrale alliancepartnere i form af ildsjæle, studenterpolitikere, ledelsesrepræsentanter m.fl., som har ytret sig om og har en klar holdning til undervisning og uddannelse. Opbyg herigennem et netværk af personer, der kan tjene som refleksions- og sparringspartnere, og som kan støtte dig i dit arbejde og i at få gennemført nødvendige tiltag. Pas på, at gruppen ikke bliver opfattet som en lukket loge, fortæl gerne om den og lad den være åben for alle. 
Uddannelsesudvikling er også uddannelsespolitik, og politik er ikke altid 'de rene hænders handlinger'. Det kan være nødvendigt at udføre lobbyarbejde, arbejde lidt i det skjulte. Ofte kan det betale sig at invitere sig selv på en kop kaffe, at fodre ledelsen med ideer, som den så selv kan fremsætte, at støtte andre af taktiske grunde osv. I min egen ledelsestid var en af de vigtigste alliancepartnere i udvikling af uddannelserne ofte de studerende. De har en umiddelbar interesse i at udvikle undervisningen, de er velorganiserede, og de er ukonventionelle og handlingsorienterede.

\section{Pas på dig selv}

Det sidste råd handler om dig selv som person. Hvis du ikke har været i en ledelsesposition $f ø r$, vil du utvivlsom blive overrasket og overvældet over arbejdsbyrden og de mange interessemodsætninger, du involveres i. Det betyder, at du har brug for støtte, både moralsk og fagligt/politisk, til at gennemføre dine visioner og konkret til at klare arbejdsbyrden. Men du skal også være opmærksom på de stress-farer, der ligger i jobbet. Hvis du føler dig stresset, "er det vigtigt, at du standser op, passer godt på dig selv og tager hånd om det, der stresser dig", står der på Lederne.dk (https://www.lederne.dk/faa-hjaelp-og-svar/trivsel-og-stress/dig-selv/stresset), hvor du kan tage en stresstest og få gode råd.

Vær opmærksom på, hvorledes studielederjobbet påvirker og indgår i din egen karriere. En garvet studieleder bemærkede ved udarbejdelsen af denne artikel, at man kan argumentere for kun at påtage sig studielederfunktionen på den sidste del af karrierevejen: "Hvis man drømmer om at blive professor, vil det være decideret dumt at blive studieleder, inden man var nået dertil, medmindre ens forskning ligger inden for uddannelse/undervisning", bemærkede hun. Så hvis du kun påtager dig studielederjobbet for at blive pedel, kan det risikere at sætte dig tilbage karrieremæssigt. Men hvis du arbejder på at realisere nogle visioner og kan fremvise resultater, kan du referere til disse senere i karrieren. Brug anledningen til din egen kompetenceudvikling, tag fx et studielederkursus eller et projektlederkursus, som både kan formalisere dine kompetencer og give støtte til at klare arbejdet, opbyg dit nationale og internationale netværk og markér dine succeser, således at du kommer styrket ud af studielederjobbet.

\section{Referencer}

Christiansen, F. V., Harboe, T., Horst, S., Krogh, L. \& Sarauw, L. L. (2013). Udviklingstenderser i universitetets rolle. I Rienecker, L., Jørgensen, P. S., Dolin, J. \& Ingerslev, G.H. (red.): Universitetspædagogik. Frederiksberg: Samfundslitteratur. s. 15-41

Dalsgård et al. (2017). https://www.altinget.dk/forskning/artikel/undervisere-her-er-de-femstoerste-problemer-med-studenterevalueringer

Damsholt, T., Jensen, H. N. og Rump, C. Ø. (red.) (2018). Videnskabelse på universitetet. Veje til integration af forskning og undervisning. København: Samfundslitteratur

Dohn, N. B. og Dolin, J. (2013). Forskningsbaseret undervisning. I: Rienecker, L.; Jørgensen, P. S.; Dolin, J. \& Ingerslev, G.H. (red.): Universitetspædagogik. Frederiksberg: Samfundslitteratur. s. 43-64

Dolin, J. og Ingerslev, G. H. (2017). Undervisning og læring. I: Dolin, J., Ingerslev, G. H. og Jørgensen, H. S. (red.): Gymnasiepædagogik. København: Hans Reitzels Forlag. s. 137155 
Harboe, T. (2012). Subtil ledelse i en ny og mere insisterende form - et kvalitativt studie af studieledere ved danske universiteter. Syddansk Universitet

Harboe, T. (2015). Danske studieledere står ved en kritisk skillevej. DUT nr. 15, s. 22-33

Harboe, T., Østerberg, C. R., Hyldegård, J. og Bruun, J. (2017). Informationskompetente studieledere - om sammenhænge mellem studielederes brug af videnskilder og deres ledelsestilgange. DUT nr. 22, s. 48-63

Hornstein, H. A. (2017). Student evaluations of teaching are an inadequate assessment tool for evaluating faculty performance. Cogent Education, 4: 1304016

Stark, P. B. \& Freishtat, R. (2014). An evaluation of course evaluations. ScienceOpen.com. doi:10.14293/S2199-1006.1.SQR-EDU. AOFRQA.v1Stark. https://www.scienceopen.com/document/vid/42e6aae5-246b-4900-8015-dc99b467b6e4?0. Hentet 30. november 2019

Udvalg for Kvalitet og Relevans i de Videregående Uddannelser (2015). Nye veje og høje mål. Kvalitetsudvalgets samlede forslag til reform af de videregående uddannelser. https://ufm.dk/publikationer/2015/nye-veje-og-hoje-mal. Hentet 30. november 2019

Udvalg for Kvalitet og Relevans i de Videregående Uddannelser (2014). Høje mål (2. delrapport). https://ufm.dk/uddannelse/rad-naevn-og-udvalg/tidligere-rad-naevn-og-udvalg/kvalitetsudvalget/publikationer/hoje-mal-rapport-2. Hentet 30. november 2019

Wiedemann, F. (2018). Studielederen. Nyttig idiot eller maskinmester? DUT nr. 24, s. 120-133

Wilson, K. L., Lizzio, A. \& Ramsden, P. (1997). The development, validation and application of the course experience questionnaire. Studies in Higher Education, 22 (1), pp. 33-53 